\title{
Economic sanctions and culture
}

Article in Defence and Peace Economics · August 2011

DOI: 10.1080/10242694.2010.500826

CITATIONS

2

3 authors, including:

Dennis Halcoussis

California State University, Northridge

24 PUBLICATIONS 153 CITATIONS

SEE PROFILE
READS

80

Some of the authors of this publication are also working on these related projects:

Project

All in: An empirical analysis of legislative voting on internet gambling restrictions in the United States View project 
This article was downloaded by: [Halcoussis, Dennis]

On: 20 November 2010

Access details: Access Details: [subscription number 929789195]

Publisher Routledge

Informa Ltd Registered in England and Wales Registered Number: 1072954 Registered office: Mortimer House, 3741 Mortimer Street, London W1T 3JH, UK

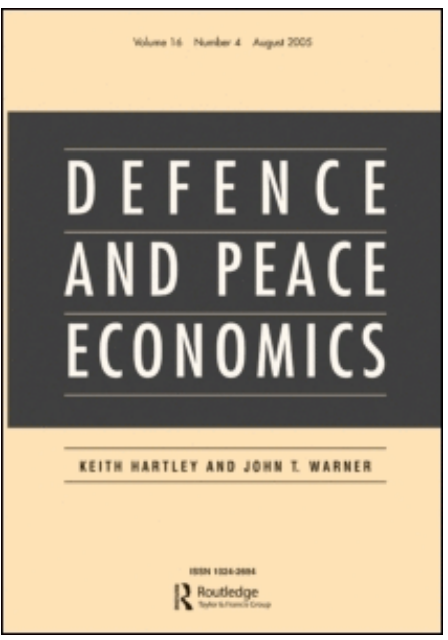

\section{Defence and Peace Economics}

Publication details, including instructions for authors and subscription information:

http://www.informaworld.com/smpp/title content=t713640174

\section{ECONOMIC SANCTIONS AND CULTURE}

Donna Driscolla; Dennis Halcoussis ; Anton D. Lowenberga

${ }^{a}$ Department of Accounting and Information Systems, California State University, Northridge, CA,

USA

First published on: 18 November 2010

To cite this Article Driscoll, Donna, Halcoussis, Dennis and Lowenberg, Anton D.(2010) 'ECONOMIC SANCTIONS AND CULTURE', Defence and Peace Economics,, First published on: 18 November 2010 (iFirst)

To link to this Article: DOI: 10.1080/10242694.2010.500826

URL: http://dx.doi.org/10.1080/10242694.2010.500826

\section{PLEASE SCROLL DOWN FOR ARTICLE}

Full terms and conditions of use: http://www.informaworld.com/terms-and-conditions-of-access.pdf

This article may be used for research, teaching and private study purposes. Any substantial or systematic reproduction, re-distribution, re-selling, loan or sub-licensing, systematic supply or distribution in any form to anyone is expressly forbidden.

The publisher does not give any warranty express or implied or make any representation that the contents will be complete or accurate or up to date. The accuracy of any instructions, formulae and drug doses should be independently verified with primary sources. The publisher shall not be liable for any loss, actions, claims, proceedings, demand or costs or damages whatsoever or howsoever caused arising directly or indirectly in connection with or arising out of the use of this material. 


\title{
ECONOMIC SANCTIONS AND CULTURE
}

\author{
DONNA DRISCOLL, DENNIS HALCOUSSIS AND ANTON D. LOWENBERG* \\ Department of Accounting and Information Systems, California State University, Northridge, 18111 \\ Nordhoff Street, Northridge, CA 91330-8372, USA
}

\begin{abstract}
We address empirically the question of why international economic sanctions are, or are not, chosen as instruments of foreign policy and the question of what determines their success. We hypothesize that cultural linkages between nations are an important factor in explaining both instrument choice and conflict outcomes. Countries that share significant cultural attributes are found to be less likely to apply economic sanctions against one another than countries lacking such cultural ties. However, it is precisely in the case of culturally similar sender and target nations that sanctions are most likely to succeed.
\end{abstract}

Keywords: Economic sanctions; Culture; International political economy; Democratic peace; Economic coercion

JEL Codes: F13; F51; F59

\section{INTRODUCTION}

The past two decades have seen a flourishing of literature, in both economics and political science, on the success, or lack thereof, of international economic sanctions as an instrument of foreign policy. The starting point for much of the empirical work on this topic is a dataset produced by Hufbauer and Schott (1985) and Hufbauer et al. (1990), hereafter HSE, which documents 116 episodes of sanctions implemented since 1914. HSE assign to each episode a success score based on the extent to which the political goals of the sanctions were attained and the extent to which the sanctions themselves contributed to the outcome. ${ }^{1}$ These success scores range in value from one to $16,{ }^{2}$ with a sanction considered successful if its score is greater than eight. HSE identify 18 potential correlates of sanctions success and, using a multiple regression model, test the impact of these correlates on the sanctions success score. The initial HSE analysis was flawed on a number of grounds, ${ }^{3}$ but it did spawn a cottage

\footnotetext{
* Corresponding author. Email: anton.lowenberg@csun.edu

${ }^{1}$ The definition of 'success' is problematic. Debate over what precisely constitutes a successful exercise of economic power in international relations has dogged the empirical sanctions literature throughout, with some scholars arguing that a sanction can be viewed as successful if it merely imposes costs on the target without eliciting a change in the target's behavior, while others have insisted that, to be deemed successful, a sanction must be the main factor contributing to the target's compliance. See Baldwin (1985), Pape (1997) and Kaempfer and Lowenberg (2007: 870-871).

${ }^{2}$ The outcome of each episode is ranked from one (failure) to four (success); the contribution of sanctions to this result is likewise ranked from one (none) to four (significant). The overall success score of the sanctions episode is then the product of the policy result score and the contribution score.
} 
industry of econometric studies that used the HSE data. The conclusions of this literature are quite mixed, the results being heavily dependent on model specification, ${ }^{4}$ but a few regularities emerge, namely that the success of sanctions is positively correlated with political instability and economic weakness in the target country (HSE; Lam, 1990; van Bergeijk, 1989, 1994) and with close, cordial ties between sanctioner and target prior to the sanctions being imposed (HSE; Lam, 1990; Bonetti, 1998) - hence HSE's well-known dictum that it is better to sanction a friend than an enemy. Many, although not all, ${ }^{5}$ empirical studies find a significant positive relationship between the cost of the sanctions to the target, measured as a percentage of the target's GNP, and the success of the sanctions (HSE; Lam, 1990; Dehejia and Wood, 1992; Dashti-Gibson et al., 1997; Drury, 1998; Hart, 2000), while Lam (1990) also finds that the cost of sanctions to the sanctioner is negatively related to sanctions success.

Another focus of inquiry in the sanctions literature, most prevalent among political scientists, is the role of domestic institutions and politics in determining both the likelihood that sanctions will be used and the political outcome of sanctions. Thus, for example, Allen (2005, 2008) finds that domestic political structures in target states, such as the susceptibility of regimes to domestic opposition, strongly influence their response to sanctions, ${ }^{6}$ while Bolks and Al-Sowayel (2000) show that a target country's institutions and the political vulnerability of its regime significantly affect the duration of sanctions episodes. Morgan and Schwebach (1995) argue that the impact of sanctions on a target country is best conceptualized in terms of their effect, direct or indirect, on the political elite. ${ }^{7}$ The main thrust of much of this literature can be summarized as the idea that the use and effects of sanctions depend crucially on the nature of the political regime in both target and sanctioner, characterized as either democratic or non-democratic.

The interest of sanctions scholars in regime type is due to the notion of a so-called democratic peace, which is a central idea in the empirical international relations literature. The democratic peace is the theory that democracies are relatively unlikely to become involved in militarized disputes with other democracies. ${ }^{8}$ This theory is normally tested empirically by comparing the warlike propensities of pairs, or dyads, of democratic countries with dyads that include at least one non-democracy.

The democratic peace approach has been extended to the study of economic sanctions, where the main issues that have been considered are whether democracies are more or less

\footnotetext{
${ }^{3}$ The explanatory power and predictive success of the HSE model is weak (Bonetti, 1997; Leitzel, 1987). Their regression equation explains only $21 \%$ of the variation in success scores and only three of the 18 coefficients used in the equation are statistically significant. One of the main reasons for these weak results is that HSE employ an ordinary least squares estimation technique that is not appropriate to the case of a limited dependent variable such as the sanctions success score (Bonetti, 1997; van Bergeijk, 1994). This problem has been addressed by various authors using discrete dependent variables estimators. For example, van Bergeijk (1989, 1994), Drury (1998) and Dehejia and Wood (1992) use logit models, Lam (1990) and Hart (2000) use probit, and Bonetti (1998) uses logistic regressions to identify the circumstances in which high levels of success or failure are probable. The HSE regression analysis has also been criticized by van Bergeijk (1994: 73) and by Lam (1990: 241) for using as a dependent variable a measure of sanctions success that includes the importance of the sanction to the attainment of the goal. This requires prejudging the extent to which a given sanctions episode caused a change in the target's policy, which is precisely what is supposed to be estimated on the right-hand side of the regression equation.

${ }^{4}$ For a survey of results, see Kaempfer and Lowenberg (2007: 892-898).

${ }^{5}$ For a contrary finding, see Jing et al. (2003).

${ }^{6}$ Allen (2008) observes that the ability of sanctions to successfully mobilize antigovernment activity in a target nation depends on the nature of domestic political institutions in that nation.

${ }^{7}$ A similar view is taken by Alerassool (1993), Smith (1995), Dashti-Gibson et al. (1997) and Selden (1999).

${ }^{8}$ For clear statements of the democratic peace hypothesis and empirical tests that confirm the specific benefits of democracy, see Russett (1993), Dixon (1994), Oneal and Russett (1997), Mousseau (1998), Russett and Oneal (2001), Dixon and Senese (2002) and Danilovic and Clare (2007). For reviews of the literature, see Russett and Starr (2000) and Weede (2004).
} 
likely than non-democracies to impose sanctions and whether sanctions are more likely to be successful against democratic or non-democratic targets. ${ }^{9}$ Little consensus has emerged from this literature, however, and our purpose in the present paper is to attempt to resolve some of these questions by expanding the notion of political regimes to include a broader array of attributes of sanctioning and target countries than is normally taken into account in sanctions studies. In particular, we argue that cultural linkages between nations involved in international disputes are an important factor in determining when economic sanctions will be applied and in determining the outcome of the sanctions. We define cultural linkages to include political, economic and social ties. This approach is implemented empirically by developing various measures of cultural 'closeness' between the sanctioning and target countries in each sanctions episode.

In the next section we survey the literature on regime type and the role of culture in explaining policy differences across nations. We bring to bear recent advances in both international relations and international political economy on the questions of instrument choice and effectiveness. Two main hypotheses emerge from the discussion in this section. First, countries that are culturally similar are less likely to apply economic sanctions against each other than culturally dissimilar countries, and, second, economic sanctions are more likely to be successful in attaining their political goals when sanctioner and target share cultural attributes than when they do not.

Section 3 describes the data and the various indexes of cultural closeness used in the study. Empirical results are reported in Section 4. The results provide some preliminary support for our contention that cultural similarity between nations tends to diminish the use of economic sanctions while also potentially enhancing their effectiveness. Moreover, our findings help to explain why the United States is such a frequent user of sanctions and why sanctions usage remains widespread despite HSE's claim that sanctions are effective only approximately onethird of the time. ${ }^{10}$

\section{REGIME TYPE, CULTURE AND ECONOMIC SANCTIONS}

As pointed out above, the democratic peace literature postulates that democratic dyads are less likely to enter into military conflict than non-democratic dyads. ${ }^{11}$ One argument that is typically made in support of this theory is that democratic political competition reveals information about a country's level of resolve, thereby avoiding escalation of disputes into violent conflict (Lektzian and Souva, 2003: 647). ${ }^{12}$ A further argument is that accountability of democratic politicians to large constituencies gives them a greater incentive to conduct successful foreign policies and protect their citizens from the costs of war (Bueno de Mesquita et al.,

\footnotetext{
${ }^{9}$ See Nooruddin (2002), Lektzian and Souva (2003), Cox and Drury (2006), Goenner (2007) and Hafner-Burton and Montgomery (2008), whose contributions are discussed further in Section 2.

${ }^{10}$ Although generally perceived as relatively ineffective instruments of foreign policy, there is evidence that sanctions are actually quite successful in ending civil wars. Escribà-Folch (2010) finds that sanctions imposed by both international institutions and by other senders have negative effects on intra-state conflict duration, either because sanctions increase the likelihood of conflict resolution or because they increase the probability of a military victory.

${ }^{11}$ Even if democracies do become embroiled in disputes with other democracies, they tend to resolve these conflicts more quickly and more peacefully than in situations where non-democracies are involved (Dixon, 1994; DeRouen and Goldfinch, 2005).

${ }^{12}$ It has also been hypothesized that the absence of liberal-democratic norms among leaders of non-democratic states creates an expectation of aggressive intentions and a presumption of enmity on the part of democratic leaders. See Farnham (2003). Gartzke (2000) attributes much of the lack of militarized disputes between democracies to preference similarity across democratic states, while Siverson and Emmons (1991) document a high rate of alliance formation among democracies.
} 
1999; 2003). ${ }^{13}$ Autocrats, by contrast, are less concerned with overall public welfare and are therefore more likely to lead their nations into military conflict. ${ }^{14}$

The democratic peace theory is by no means uncontroversial, however, with some scholars disputing both the logical basis and the empirical evidence for it. ${ }^{15}$ Nevertheless, it has clearly been influential in the sanctions literature. Thus, Lektzian and Souva (2003), Cox and Drury (2006) and Goenner (2007) investigate whether there is an analogous 'economic peace' between democracies, i.e. whether democracies are relatively unlikely to use economic sanctions against other democracies. The same factors that encourage peace among democracies - a greater ability to send clear signals of resolve and a greater dependence of democratic politicians on successful policies - are expected to operate in the realm of sanctions (Lektzian and Souva, 2003: 647). Lektzian and Souva's (2003), Cox and Drury's (2006) and Goenner's (2007) results all show that democracies impose sanctions more often than other regime types. Lektzian and Souva (2003: 644-645) hypothesize that this propensity to sanction is due to the fact that the ruling coalitions in democracies encompass a greater variety of interest groups that need to be satisfied. Trade sanctions are useful particularly to democratic governments as a device to justify protection for domestic industries while still professing commitment to a liberal trading regime (Cox and Drury, 2006). ${ }^{16}$ Cox and Drury add that democracies might choose sanctions over military action because non-violent measures generally attract less public attention and opposition. ${ }^{17}$ Goenner (2007) maintains that, precisely because the public views sanctions as more acceptable than militarized conflict, the usual conflict-inhibiting effects of democratic norms and institutions are weakened when it comes to the use of sanctions.

At the same time, however, Lektzian and Souva (2003), Cox and Drury (2006) and Goenner (2007) also find that democracies are more likely to sanction non-democracies than other democracies. ${ }^{18}$ Cox and Drury suggest that this result occurs because two of the most common reasons that democracies impose sanctions - to promote democracy and to punish human rights violations - apply largely to autocratic targets; democratic states, by definition, are usually not the ones guilty of abusing their citizens' political or human rights. Moreover, according to Lektzian and Souva (2003: 648), given the strong imperative for democratic leaders to pursue successful foreign policies, they will typically prefer to pick on non-democratic

\footnotetext{
${ }^{13}$ For empirical tests of various competing theories of the democratic peace, see Lektzian and Souva (2009). It is of course conceivable that the direction of causality might be quite the reverse of that postulated in the democratic peace literature, i.e. that the observed rarity of war between democracies might be explained by a negative effect of war on democracy rather than vice versa. For example, it is plausible to suppose that nations become more autocratic as they prepare for impending wars. Mousseau and Shi (1999) test this hypothesis but find that disputant countries are in fact equally likely to become more democratic as they are to become more autocratic in periods leading up to the outbreak of wars. James et al. $(1999,2000)$ reject single equation estimates of the relationship between democracy and war as merely ad hoc reduced forms, lacking in causal inference. In their view, a more appropriate methodology would be to identify a structural equation as part of a simultaneous system in which both democracy and conflict are treated as endogenous. Using a simultaneous equations model, Reuveny and Li (2003) find that dyadic militarized disputes reduce joint democracy while at the same time joint democracy reduces the probability of militarized disputes.

${ }^{14}$ Bueno de Mesquita and Siverson (1995) find empirical evidence that engaging in war is hazardous to the survival in office of all types of leaders, but especially democrats.

${ }^{15}$ For critical perspectives on the democratic peace, see Hess and Orphanides (2001), Rosato (2003, 2005), Henderson $(1999,2002)$ and Ward et al. (2007).

${ }^{16}$ As Kaempfer and Lowenberg (1988) point out, majoritarian democracies are especially vulnerable to pressure from interest groups to impose sanctions, sometimes motivated by moral outrage against the objectionable behavior of a foreign state, but often driven by little more than thinly disguised protectionist interests in trade restrictions.

${ }^{17}$ Nevertheless, as Lektzian and Sprecher (2007) demonstrate, sanctions implemented by democracies are frequently followed by the use of military force.

${ }^{18}$ This finding is disputed by Hafner-Burton and Montgomery (2008) on the grounds that it is derived from a flawed empirical method that fails to take account of the disproportionate weight of the United States among sanctioners.
} 
targets on the grounds that a democratic target "will take all necessary means to offset or counter the sanctions in an effort to continue providing a stream of public goods to members of its broad winning coalition.'

The belief that democracies are more motivated than non-democracies both to use sanctions and to resist the demands of external sanctioners derives in part from Fearon's (1994) notion of audience costs. These are the costs in terms of forgone political support that are incurred by a nation's leaders when the public becomes disillusioned with their leaders' abilities. According to Fearon, a democracy, which faces high domestic audience costs, is always less likely to back down in a public confrontation during an international crisis than a non-democracy, whose audience costs are considerably lower and which consequently has greater flexibility to alter its policies in response to foreign pressure. ${ }^{19}$ It follows that a signal of resolve sent by a democratic target of sanctions will be more credible than one sent by an autocratic target, so that a potential democratic sanctioner, itself constrained by its own domestic political institutions to avoid foreign policy failures, ${ }^{20}$ is less likely to initiate sanctions against a democratic target (Lektzian and Souva, 2003: 648). In one of the classics of the sanctions literature, Galtung (1967) lends further credence to the relative resilience of democratic targets by pointing out that democracies have greater legitimacy and are therefore more likely than autocracies to rally their citizens around the flag of resistance to sanctions. ${ }^{21}$

However, like its political counterpart in the democratic peace literature, the economic peace hypothesis is contentious. In particular, the claim that a democratic target is less likely to concede to sanctions than a non-democracy is rejected by many scholars. For example, Nooruddin (2002: 69-70) argues that, precisely because democratic political leaders are compelled to take into account their public's preferences, it is probable that a democratic target government would agree to the sanctioners' demands in order to get the sanctions lifted and relieve the suffering of its constituents. Similarly, Bolks and Al-Sowayel (2000) show that democratic governments typically do not resist sanctions for long because of the resulting domestic political costs that their electorates would impose upon them. Much the same argument is proposed by Nossal (1999: 130), who notes that political leaders in target nations who fail to alter their behavior in order to put a stop to the economic pain caused by sanctions risk being ejected from office. ${ }^{22}$ By contrast, in non-democracies, Pape (1997: 93) points out that unpopular ruling elites can often protect themselves and their supporters by shifting the economic burden of sanctions on to disenfranchised groups. ${ }^{23}$ According to Bolks and AlSowayel (2000), when the leadership of a state is concentrated in the hands of a few, the leadership is better able to implement countermeasures that insulate the government from the economic hardships caused by sanctions. Non-democratic and illiberal regimes find it especially easy to hold out in the face of damaging sanctions because they can 'simply pass on the

\footnotetext{
${ }^{19}$ In an empirical test of Fearon's theory, Partell and Palmer (1999) find that domestic political audiences do indeed exert a strong influence over which countries in a crisis are likely to achieve successful outcomes, although relative national capabilities are also found to be important.

${ }^{20}$ Hart (2000) suggests that democracies are generally more successful sanctioners than non-democracies because the audience costs confronted by democratic governments ensure that they will choose to apply sanctions in the first place only if they are committed to holding out for success.

${ }^{21}$ This rally-around-the-flag effect has captured the attention of many scholars in the sanctions literature. See, for example, Mayall (1984: 631) and Mack and Khan (2000: 282). Moreover, as Galtung (1967) points out, sanctions can be counterproductive by giving rise to a new elite in the target country that benefits from international isolation. On such unintended consequences, see also Doxey $(1980,1996)$ and Selden (1999).

${ }^{22}$ Drawing on a large panel of cross-country and time-series data, Marinov (2005) finds empirical evidence for the destabilizing effect of foreign economic pressure on the leadership of target countries.

${ }^{23}$ Pape (1997) cites the case of Iraq in the 1990s, which, despite facing the most damaging economic sanctions in history, with $48 \%$ of its GNP destroyed, did not acquiesce.
} 
costs of the sanctions to the governed and rely on armed forces to deter political opponents who are dissatisfied with policies' (Nossal, 1999: 134). ${ }^{24}$

In any case, as Lektzian and Souva (2007) observe, non-democratic leaders, with their smaller winning coalitions, have fewer core constituents who are hurt by sanctions than do democratic leaders. Moreover, pervasive nationalism often makes citizens of non-democratic states willing to endure considerable punishment rather than abandon policies that are seen to be in the national interest (Pape, 1997: 93). Cortright and Lopez (2000: 214) argue that 'sanctions provide authoritarian governments with leverage to create a 'rally-around-the-flag' effect as a means of suppressing domestic opposition. ${ }^{25}$ Damrosch (1993: 299) contends that sanctions will almost inevitably benefit an autocratic regime because the regime will always be in a better position than the civilian population to control external transactions and the internal economy. ${ }^{26}$ In Damrosch's view, the creation and enrichment of a criminal class that profiteers from trading bootleg or scarce goods means that even the most skillfully targeted sanctions will serve only to entrench the power of the ruling elite. ${ }^{27}$

Bolks and Al-Sowayel (2000) and Nooruddin (2002: 73) present empirical evidence that sanctions imposed against autocratic targets are less successful than those imposed against democracies. Nooruddin (2002: 69-70) draws the logical conclusion that sanctioners are therefore more likely to sanction democracies than non-democracies precisely because democracies are more likely to concede. ${ }^{28} \mathrm{~A}$ further argument supporting the claim that democracies, in particular, are inclined to use sanctions against democratic adversaries is the observation that democracies prefer to substitute non-military coercion, including sanctions, for militarized tools of foreign policy when confronting other democracies in inter-state disputes (Palmer et al., 2002; Morgan and Palmer, 2003). ${ }^{29}$

In the democratic peace literature, some theorists (e.g., Henderson, 1998; Mousseau, 2003, 2009) have suggested that cultural or normative attributes of states might play a role in determining the incidence of war between them. The presumption here is that countries that are relatively similar in culture may be less likely to go to war against each other. In an empirical test of this hypothesis, Henderson (1998) finds that, although cultural factors are significant correlates of war, they do not diminish the impact of joint democracy. Among cultural variables, he finds that religious similarity between pairs of countries is associated with a decreased likelihood of war, while ethnic and linguistic similarities have the opposite effect. Political institutions, such as democracy or the lack thereof, are themselves often closely associated with the presence of certain cultural attributes. For example, Henderson (1998) points

\footnotetext{
${ }^{24}$ Peksen (2009) reports empirical evidence that sanctions are more likely to bring about a deterioration in human rights conditions in target countries than an improvement. A similar finding is obtained by Wood (2008), who argues that the negative impact of sanctions on human rights is due to the fact that target states frequently respond to sanctions by tightening repression in an attempt to stabilize their regimes, protect core supporters, minimize opposition threats and quell popular dissent.

${ }^{25}$ On the tendency of sanctions to strengthen the 'hawks' and weaken the 'doves,' see Willett and Jalalighajar (1983/84).

${ }^{26}$ Lektzian and Souva (2007) point out that the rents generated by sanctions typically benefit non-democratic leaders to a greater extent than they benefit democratic ones. On the capture of sanctions rents by autocratic rulers, see also Kaempfer and Lowenberg (1999) and Kaempfer et al. (2004).

${ }^{27}$ For theoretical treatments of the political effects of sanctions on non-democracies, see Wintrobe $(1990,1998)$, Kaempfer et al. (2004) and Mulligan and Tsui (2006, 2008).

${ }^{28}$ This finding does not necessarily refute the notion of an economic peace among democracies, however. The economic peace is a dyadic phenomenon (Lektzian and Souva, 2003: 647); it requires that pairs of democratic countries be less likely to be involved in sanctions than pairs of non-democratic countries or mixed pairs. Although Nooruddin finds that democracies are more likely to be targets of sanctions, he does not test whether democracies are also more likely than non-democracies to impose sanctions. In fact, Nooruddin's data include only US-imposed sanctions (Nooruddin, 2002: 63, 70).

${ }^{29}$ There is some evidence, however, that democracies favor the use of positive economic incentives rather than sanctions, especially in dealing with other democracies (Davidson and Shambaugh, 2000; Drezner. 2000).
} 
out that democratic dyads typically have higher religious similarity levels than nondemocratic dyads, while Bernhard et al., (2004) find that Western overseas colonialism has a positive effect on the survival of democratic regimes.

In fact, colonial legacy has been shown to be an important source of institutional variation across countries. Differences in legal and constitutional systems, as well as in political and economic freedom, have been attributed, at least in part, to the transplantation of colonial institutions, ${ }^{30}$ as have differences in economic performance across developing countries (Acemoglu et al., 2001, 2002b; Levine, 2005; Easterly, 2006). ${ }^{31}$ There is much consensus that democratic political institutions are instrumental in sustaining those economic institutions that encourage growth, most notably secure property rights and contract enforcement. ${ }^{32}$ Tabellini (2010) reports empirical evidence of the significance of historically-determined components of culture - such as trust, respect for others and confidence in the payoff to individual effort as independent causes of current economic performance. ${ }^{33}$ Hillman and Swank (2000) note the role of political culture in explaining differences in policies across countries.

The literature discussed above suggests that cultural characteristics of states - broadly defined to include elements of political, economic and social culture - are important determinants of both institutions and policy outcomes. The purpose of the present paper is to examine the role of cultural similarity, or dissimilarity, between nations in explaining sanctioning behavior. We define political culture to include colonial linkages as well as similarities in degree of democracy, civil and political liberties, electoral systems and forms of government. Economic culture includes protection of property rights, freedom of exchange and freedom from excessive government regulation as measured by the size of the government sector relative to the overall economy. Social culture refers primarily to ethnicity, religion and language.

By considering a wider range of cultural variables than merely regime type, we hope to resolve some of the indeterminacy in the existing literature on the use and effects of sanctions. Two questions arise in this regard. First, how do the various cultural attributes identified above influence the choice of instrument, i.e. whether or not sanctions are used? Second, to what extent are cultural factors important in determining the success of sanctions in attaining their intended political goals?

States with similar political and economic institutions can be expected to have similar foreign policy preferences and therefore to be less likely to enter into conflict with one another (Souva, 2004). We extend this argument by hypothesizing that countries that share significant cultural attributes may be less likely to apply economic sanctions against one another, possibly because they have access to alternative avenues of pressure that they can bring to bear in a dispute, e.g. cultural embargoes,${ }^{34}$ kinship networks and other informal points of contact. Kaempfer and Lowenberg (1999) point out that such symbolic or non-economic measures become more effective the closer the sanctioner is to the target in terms of culture or common interests. Non-economic sanctions, which involve severing cultural links, can be aimed selectively by pinpointing those values or ideals cherished by target groups within the sanctioned polity. Many scholars have noted the superiority of such narrowly targeted instruments - often

\footnotetext{
${ }^{30}$ See, for example, La Porta et al. (1999, 2002, 2008), Beck et al. (2003), Levine (2005).

${ }^{31}$ Grier (1999) and Feyrer and Sacerdote (2009) show that time spent under European colonial rule is positively associated with economic development. See also Bertocchi and Canovab (2002) on the effects of colonization on Africa's development performance and Acemoglu et al. (2002a) on colonial institutions as the main cause of Botswana's impressive growth record.

${ }^{32}$ See Knack and Keefer (1995), Olson (1996), Clague et al. (1999), Rodrik (2000a, 2000b), Feng (2003), Acemoglu et al. (2004), Doucouliagos and Ulubaşoğlu (2008) and Mijiyawa (2008). Helpman (2004) provides a review of research on the growth effects of institutions, including property rights protection, legal systems, customs and political systems.

${ }^{33}$ See also Tabellini (2008)

${ }^{34}$ Cultural embargoes include restrictions on educational, artistic and sporting links with a target country.
} 
referred to as 'smart sanctions' - over those whose impacts are more indiscriminate. ${ }^{35}$ While economic sanctions do not lend themselves very easily to fine-tuning (Tostensen and Bull, 2002), non-economic measures are inherently selective. Moreover, symbolic sanctions, because they presuppose close cultural affinity between sanctioner and target, are necessarily unilateral rather than multilateral, or at least involve only a small group of sanctioners. ${ }^{36}$ An absence of cultural or historical ties with former colonies could explain why the United States is such a frequent user of economic sanctions compared to European ex-colonial powers. ${ }^{37}$

We also hypothesize, however, that once economic sanctions have been selected as the policy of choice, the sanctions are more likely to be successful in achieving their political objectives when sanctioner and target are culturally similar than when they are not. The democratic peace literature discussed above suggests that countries that share participatory political institutions may be in a better position to signal levels of resolve or commitment in international disputes than countries lacking such institutions. Analogously, we argue that a sanctions episode is more likely to be successful for the sanctioning country when sanctioner and target share a range of cultural attributes. Such a phenomenon would not only be consistent with HSE's (1990) prediction that sanctions against a friend are more likely to succeed than sanctions against an enemy, but, taken together with our first hypothesis, could also be considered a variant of Drezner's $(1998,1999)$ 'sanctions paradox.' In Drezner's case, the paradox arises because sanctions imposed against allies are most likely to produce significant concessions, ${ }^{38}$ and yet most sanctions are imposed against adversaries. Likewise, in our case, economic sanctions are most likely to be successful when involving culturally similar countries, and yet countries that are culturally similar are precisely the ones that are least likely to use economic sanctions against each other, preferring instead to rely on non-economic measures.

In order to test our hypotheses we need to develop empirical measures of the various relevant dimensions of cultural 'closeness' between countries. There is considerable precedent for such measures in the literature. For example, Goodfriend and McDermott (1998: 1280) define a 'familiarity' parameter that includes, among other things, geographical proximity, active commercial relations and a common language. They use this parameter to explain the flow of technical knowledge between countries. Along similar lines, Rauch (1999) shows that proximity, common language and colonial ties are important in explaining international trade in differentiated products. ${ }^{39}$ In the next section we specify a series of measures that are intended to capture the elements of cultural closeness discussed above, which we expect to play a role in determining when economic sanctions are imposed and how effective they are.

\footnotetext{
${ }^{35}$ It is often argued that smart sanctions are not only more effective than broad, GNP-reducing sanctions in achieving their objectives but are also less likely to impose 'collateral damage' on innocent groups within the target country, such damage having the undesired effect of potentially strengthening the regime and retarding the emergence of a middle class and civil society (Haass, 1998: 202). On smart sanctions, see also Weiss (1999), Cortright and Lopez (2000, 2002a, 2002b), Lopez (2001), Cortright, Lopez and Rogers (2002), Cortright, Millar and Lopez (2002).

${ }^{36}$ Kaempfer and Lowenberg (1999) offer the example of the sports embargo on apartheid South Africa, imposed by a handful of rugby- and cricket-playing nations, which arguably had a greater impact on whites in that country, without hurting blacks much, than did many of the severest economic sanctions that were applied. On sanctions that entail proscriptions on cultural activities and sporting events, see Hanlon and Omond (1987: 225).

${ }^{37}$ On the propensity of the United States to resort to sanctions, see Hufbauer (1998).

${ }^{38}$ According to Drezner $(1998,1999)$, sanctions outcomes are determined in part by expectations of future conflict. The reason for the greater success rate of sanctions against allies than against adversaries is that allies are less concerned about the relative gains of holding out for a better bargaining position in the future, due to a low expected likelihood of future conflict.

${ }^{39}$ Spolaore and Wacziarg (2009) examine the effects of genealogical 'relatedness' between populations on interstate conflict, while Guiso et al. (2009) find that bilateral trust between European nations, which is driven partly by cultural similarities, influences the amount of trade and investment flows between them.
} 


\section{THE DATA}

The empirical sanctions literature has been criticized for selection bias because the HSE data include only those episodes in which sanctions were actually applied. There are many other instances in which sanctions were considered or threatened but ultimately not used. Morgan and Miers (1999), Hart (2000) and Nooruddin (2002) argue that economic coercion is typically applied only in the most intractable of situations, in which irreconcilable differences between sanctioner and target make it unlikely that the sanctions will succeed in changing the target's behavior. It follows that studies focusing on only those sanctions that are implemented will necessarily be biased against sanctions success (Blake and Klemm, 2006). Lacy and Niou (2004) demonstrate that not only are sanctions most likely to be imposed precisely when they are not likely to succeed, but the sanctions that are likely to succeed will do so as threats, without having to be imposed at all. ${ }^{40}$ In order to address this problem, Drezner $(2001,2003)$ surveys cases in which sanctions were applied in pursuit of economic or regulatory goals. In these categories of sanctions, threats are often made publicly before sanctions are implemented, providing an ideal test for selection bias. Drezner's results show that the sanctions that generated significant concessions were indeed most likely to end at the threat stage. ${ }^{41}$ However, the view that empirical sanctions studies are biased against sanctions success is by no means universal. If sender countries behave strategically by imposing sanctions only when they believe them to have a good chance of working, then empirical studies based on actuallyimplemented sanctions would be biased in favor of sanctions success. The overall conclusion is that sanctions that are actually implemented 'constitute a very unrepresentative tip of an iceberg' (Eaton and Engers 1999: 410).

The problem of selection bias is part of a broader issue, namely that the mechanisms determining whether sanctions are used are inherently connected to the mechanisms determining their success (Smith, 1995; Morgan and Miers, 1999; Hart, 2000; Bolks and Al-Sowayel, 2000; Nooruddin, 2002; Jing et al., 2003). From an empirical standpoint, the problem is that the choice of policy instrument, e.g. trade sanctions, financial sanctions, or military intervention, is endogenous to the political process and, in particular, to the policy outcome sought by the sanctioner. But the choice of instrument also affects the outcome of the sanctions. Therefore, some of the variables that explain the effectiveness of sanctions, e.g. the types of sanctions that are chosen or the design of the sanctions strategy, are themselves explained by other right-hand side variables. Jing et al. (2003) address this endogeneity issue by estimating a simultaneous equations model in which the sanctions policy outcome and the probabilities of the sanctioner's adoption of different sanctions instruments are jointly determined. ${ }^{42}$ Their results confirm some findings of the earlier literature but also reveal some key differences. ${ }^{43}$ The endogeneity problem discussed here arises in the present study too, and the method used to deal with it is described in the next section.

\footnotetext{
${ }^{40}$ In the words of Eaton and Engers (1992: 902), 'sanctions can be effective even if, in equilibrium, they are not actually used.' See also Blake and Klemm (2006).

${ }^{41}$ The finding that threats are normally more effective than actually-implemented sanctions is disputed by Krustev (2010), who contends that this result is an artifact of exogenous policy objectives on the part of sanctioners. If the demands of sanctioners are treated instead as endogenous, determined strategically by the capabilities and interests of target states, then the apparently paradoxical tendency of actually-implemented sanctions to be selective of the most difficult disputes is explained and it is no longer necessarily the case that threats are more effective than sanctions. Of course, sanctions are often threatened or applied not to achieve a given policy objective of the target country but for expressive or demonstrative purposes, e.g. to signal disapproval or resolve, to establish a reputation in the eyes of domestic and foreign audiences, or merely to be seen to be 'doing something.' See Galtung (1967), Renwick (1981), Leyton-Brown (1987), Lundborg (1987) and Tsebelis (1990).

${ }^{42}$ Another two-stage estimation approach that has been used to deal with the problem of simultaneity of instrument choice and effectiveness is the censored probit model, exemplified by Nooruddin (2002).

${ }^{43}$ For a comparison of results, see Kaempfer and Lowenberg (2007: 892-898).
} 
We use countries from the HSE dataset from 1914 to $1990^{44}$ to form 1972 dyads, 98 of which represent an economic sanction that took place. Note that a particular combination of countries can occur more than once within this subset of 98 dyads; for example, the United States imposed economic sanctions against Iran twice, in 1951 and in 1984. The other 1874 dyads represent combinations of countries between which no economic sanctions have occurred between 1914 and 1990. Here, we focus on cultural ties between nations and how these ties affect the probability of an economic sanction occurring and the effectiveness of a sanction if it does occur. These cultural ties do not change much from year to year; therefore, it is infeasible to utilize yearly dyads for each possible combination as done in other studies such as Nooruddin (2002), Lektzian and Souva (2003), Cox and Drury (2006) and Hafner-Burton and Montgomery (2008). Such a dataset would contain a large degree of multicollinearity, since any measure of cultural ties would not show much variation over time.

Table I lists the 63 countries included in the 1972 dyads. These dyads are used to examine the probability of an economic sanction occurring, considering the cultural and economic circumstances of the two countries in the dyad. We also estimate a probit model using 1383 of these dyads (not all of the independent variables are available for all 1972 dyads). Next, we want to examine how cultural and economic conditions affect the likelihood that the sanction will be successful. For this part of the study, 138 dyads are used, containing 46 countries, all of which were involved in a sanctions episode at some point in time. These countries are listed separately in Table I. This sample was chosen to avoid selection bias; the methodology for the sample selection is discussed below.

The following variables are used in the study.

SUCCESS: Measures the success of an economic sanction for each dyad. It is the measure described in Section 1, from Hufbauer et al. (1990), unless the dyad is one that did not have an economic sanction, in which case this variable is assigned a value of zero.

CULTURE: For each dyad, CULTURE measures the degree of similarity of social culture, defined largely in terms of geographical proximity. Calculated from the measure used by Paldam (2002), geographical groupings consist of (i) 19 'old' OECD countries, (ii) 16 Latin American countries, (iii) 24 'old communist' countries, (iv) 15 sub-Saharan African countries, (v) 11 'Oriental' countries, and (vi) 15 residual (ungrouped) countries. The methodology used to calculate CULTURE is described below.

CIVILLIB: For each dyad, CIVILLIB measures the degree of similarity of civil liberties possessed by the citizens of the two countries. It is constructed from Freedom House (2005) data available at http://www.freedomhouse.org/template.cfm?page $=211 \&$ year $=2005 .{ }^{45}$

\footnotetext{
${ }^{44}$ The HSE dataset has since been updated to include sanctions episodes after 1990. See Hufbauer et al. (2007). Although we did not test our hypotheses with the newer data, which were released only after we had commenced our study, we have no a priori reason to believe that the fundamental role of culture was any different after 1990 than it was before, despite the fact that the degree of similarity of political and economic culture within some dyads might have changed with the end of the Cold War.

45 1972-1973 civil liberties data were used for any sanctions occurring before 1972. Pre-1972 sanctions arise in only $2.6 \%$ of the 1972 dyads used in the first set of tests in the study, and in $21 \%$ of the 138 dyads used in the second part of the study. However, in the latter case, some of the pre-1972 sanctions are very close to 1972, with only $18 \%$ of sanctions occurring before 1970. Omitting this variable from the analysis did not significantly affect the estimates for the other variables.
} 
TABLE I Countries Used to Form Dyads

Countries used to form dyads for full sample

\begin{tabular}{|c|c|c|c|}
\hline 1. Albania & 40. Pakistan & 1. Angola & 40. Tunisia \\
\hline 2. Angola & 41. Paraguay & 2. Argentina & 41. Turkey \\
\hline 3. Argentina & 42. Peru & 3. Bolivia & 42. Uganda \\
\hline 4. Australia & 43. Portugal & 4. Brazil & 43. United Kingdom \\
\hline 5. Biafra & 44. Romania & 5. Canada & 44. United States \\
\hline 6. Bolivia & 45. Somalia & 6. Chile & 45. Uruguay \\
\hline 7. Brazil & 46. South Africa & 7. China & 46. Zimbabwe \\
\hline 8. Canada & 47. South Korea & 8. Dominican Republic & \\
\hline 9. Ceylon & 48. South Vietnam & 9. Egypt & \\
\hline 10. Chile & 49. Spain & 10. El Salvador & \\
\hline 11. China & 50. Sudan & 11. Ethiopia & \\
\hline 12. Cuba & 51. Suriname & 12. France & \\
\hline 13. Dominican Republic & 52. Syria & 13. Guatemala & \\
\hline 14. Egypt & 53. Taiwan & 14. Haiti & \\
\hline 15. El Salvador & 54. Tunisia & 15. India & \\
\hline 16. Ethiopia & 55. Turkey & 16. Indonesia & \\
\hline 17. Finland & 56. U.S.S.R. & 17. Iran & \\
\hline 18. France & 57. Uganda & 18. Iraq & \\
\hline 19. Germany & 58. United Kingdom & 19. Israel & \\
\hline 20. Guatemala & 59. United States & 20. Italy & \\
\hline 21. Haiti & 60. Uruguay & 21. Japan & \\
\hline 22. Hyderabad & 61. Vietnam & 22. Lesotho & \\
\hline 23. India & 62. Yugoslavia & 23. Malaysia & \\
\hline 24. Indonesia & 63. Zimbabwe & 24. Mexico & \\
\hline 25. Iran & & 25. Nepal & \\
\hline 26. Iraq & & 26. Netherlands & \\
\hline 27. Israel & & 27. Nicaragua & \\
\hline 28. Italy & & 28. Pakistan & \\
\hline 29. Japan & & 29. Paraguay & \\
\hline 30. Kampuchea & & 30. Peru & \\
\hline 31. Laos & & 31. Portugal & \\
\hline 32. Lesotho & & 32. Somalia & \\
\hline 33. Malaysia & & 33. South Africa & \\
\hline 34. Mexico & & 34. South Korea & \\
\hline 35. Nepal & & 35. Spain & \\
\hline 36. Netherlands & & 36. Sudan & \\
\hline 37. Nicaragua & & 37. Suriname & \\
\hline 38. Nigeria & & 38. Syria & \\
\hline 39. North Vietnam & & 39. Taiwan & \\
\hline
\end{tabular}

Countries used to form dyads for ordinal regression sample (no independent variables missing)
1. Angola
2. Argentina
4. Brazil
7. China
9. Egypt
10. El Salvador
11. Ethiopia
12. France
13. Guatemala
14. Haiti
15. India
16. Indonesia
17. Iran
18. Iraq
19. Israel
20. Italy
21. Japan
22. Lesotho
23. Malaysia
24. Mexico
25. Nepal
26. Netherlands
27. Nicaragua
28. Pakistan
29. Paraguay
30. Peru
31. Portugal
32. Somalia
33. South Africa
34. South Korea
35. Spain
36. Sudan
37. Suriname
9. Taiwan

40. Tunisia

22. Ugand

43. United Kingdom

44. United States

45. Uruguay

POLRIGHTS: For each dyad, POLRIGHTS measures the degree of similarity of political rights possessed by the citizens of the two countries. It is constructed from Freedom House (2005) data available at http://www.freedomhouse.org/template.cfm?page $=211 \&$ year $=2005 .^{46}$

\footnotetext{
${ }^{46} 1972-1973$ political rights data were used for any sanctions occurring before 1972. See previous note. Again, omitting this variable from the analysis did not significantly affect the estimates for the other variables.
} 
GOVGDP: For each dyad, GOVGDP measures the degree of similarity of the two countries in terms of the percentage of GDP that is collected by the government as tax revenue. Most values are from the Penn World Table (Heston et al., 2002). Values for countries that are missing from the Penn World Table are from the United Nations Statistics Division (http:// unstats.un.org/unsd/snaama/Introduction.asp), with the base year adjusted to 1996 so as to be compatible with the Penn World Table data. ${ }^{47}$

GDPPOP: For each dyad, GDPPOP measures the degree of similarity of the two countries in terms of real GDP (1996 prices) divided by population. This variable was constructed from the same sources as GOVGDP.

TRADEGDP: For each dyad, TRADEGDP measures the degree of similarity of the two countries in terms of trade dependence, defined as the sum of exports and imports divided by GDP. This variable was constructed from the same sources as GOVGDP.

TARGETDEM: A dummy variable equal to one if the target country is a democracy, zero otherwise (for dyads where a sanction did not occur, one country was chosen at random to serve as the target country). This variable was constructed from information obtained from the US Central Intelligence Agency (https://www.cia.gov/library/publications/the-worldfactbook/index.html) and from the US Department of State (http://www.state.gov/r/pa/ei/ $\operatorname{bgn} /)$.

BOTHDEM: A dummy variable equal to one if both the sanctioning and target countries in a dyad are democracies, zero otherwise. This variable was constructed from the same sources as TARGETDEM.

GOVSIM: An index that measures the similarity of the forms of government in the two countries in a dyad. See the Appendix for details.

COLONY: A dummy variable equal to one if the two countries in a dyad had, or still have, a colonial relationship, zero otherwise. The presence of a colonial relationship between the two countries means either that one country was, at some point in history, a colony of the other, or that both countries were colonies of the same colonial power.

Table II gives descriptive statistics for these variables, and also provides descriptive statistics for sub-samples of dyads in which economic sanctions occurred and did not occur. TARGETDEM, BOTHDEM, and COLONY are all traditional dummy variables that take values of only zero or one. CULTURE, CIVILLIB, POLRIGHTS, GOVGDP, GDPPOP, TRADEGDP and GOVSIM are all variables that measure the similarity of some attribute of the two nations in each dyad. The general method used to construct these variables (with the exception of GOVSIM, described in the Appendix) is to take the range of the underlying attribute variable, subtract the absolute value of the difference between the values of the attribute variable for the two countries in the dyad, and then divide by the standard deviation of the attribute variable. For example, for CIVILLIB, the formula is:

\footnotetext{
${ }^{47} 1950$ GOVGDP data were used for any sanctions occurring before 1950 . Pre-1950 sanctions arise in less than $1 \%$ of the 1972 dyads used in the first set of results, and in none of the 138 dyads used in the second part of the study. The same holds for GDPPOP and TRADEGDP.
} 
TABLE II Means and Standard Deviations for Entire Sample, Sanctions Dyads and Non-Sanction Dyads

\begin{tabular}{|c|c|c|c|c|c|c|c|c|}
\hline \multirow[b]{2}{*}{ Variable } & \multicolumn{4}{|c|}{$\begin{array}{c}\text { Entire sample } \\
n=1439-1972^{a}\end{array}$} & \multicolumn{2}{|c|}{$\begin{array}{l}\text { Sanctions dyads } \\
n=69-98^{a}\end{array}$} & \multicolumn{2}{|c|}{$\begin{array}{l}\text { Non-sanction dyads } \\
n=1423-1874^{a}\end{array}$} \\
\hline & Min & $\operatorname{Max}$ & Mean & $\begin{array}{l}\text { Standard } \\
\text { deviation }\end{array}$ & Mean & $\begin{array}{l}\text { Standard } \\
\text { deviation }\end{array}$ & Mean & $\begin{array}{l}\text { Standard } \\
\text { deviation }\end{array}$ \\
\hline SUCCESS & 0.00 & 16.00 & 0.3372 & 1.84217 & 6.7857 & 4.97468 & 0.0000 & 0.00000 \\
\hline CULTURE & 0.00 & 2.59 & 1.460 & 0.85837 & 1.1963 & 0.9825 & 1.474 & 0.8490 \\
\hline CIVILLIB & 0.00 & 3.10 & 1.9703 & 0.84909 & 1.4358 & 0.88407 & 2.0010 & 0.83701 \\
\hline POLRIGHTS & 0.00 & 2.82 & 1.7009 & 0.86684 & 1.2451 & 0.96319 & 1.7259 & 0.85456 \\
\hline GOVGDP & 0.00 & 6.42 & 4.5705 & 0.94102 & 5.4251 & 0.89470 & 4.5261 & 0.92224 \\
\hline GDPPOP & 0.05 & 6.42 & 2.7556 & 1.06675 & 5.4146 & 0.90595 & 2.6229 & 0.88530 \\
\hline TRADEGDP & 0.00 & 6.02 & 3.9682 & 0.92771 & 4.9062 & 0.98060 & 3.9209 & 0.89982 \\
\hline TARGETDEM & 0.00 & 1.00 & 0.2028 & 0.40222 & 0.2449 & 0.43224 & 0.2006 & 0.40059 \\
\hline GOVSIM & 0.65 & 7.00 & 3.2778 & 1.44438 & 3.7006 & 1.76079 & 3.2541 & 1.42146 \\
\hline COLONY & 0.00 & 1.00 & 0.1344 & 0.34115 & 0.1531 & 0.36190 & 0.1334 & 0.34010 \\
\hline
\end{tabular}

${ }^{\text {a }}$ The sample sizes differ by variable because not all variables are available for each dyad.

\section{((7-1)-| Civil Laberties score for Nation A-Civil Liberties score for Nation B |) st. dev. of Civil Liberties score for sample}

Seven is the maximum Freedom House (2005) civil liberties score over the sample, and one is the minimum. Thus, if two nations have the same civil liberties score, say three, the value of CIVILLIB would be maximized. (In this case, the value of the numerator would be (7-1)-(3$3)=6$.) If two countries have civil liberties scores that are the maximum distance from each other, then the value of CIVILLIB is minimized. (In this case, the value of the numerator would be $(7-1)-(7-1)=0$.) The numerator is divided by the standard deviation to make the estimated regression coefficients, presented later, comparable to each other. CULTURE, CIVILLIB, POLRIGHTS, GOVGDP, GDPPOP and TRADEGDP are all calculated following this same methodology. Defining the variables in this manner gives results that are similar in meaning to those of standardized coefficients, making the results easier to interpret.

To get a better idea of how the independent variables work in practice, CULTURE, CIVILLIB and POLRIGHTS are compared for three specific examples. Consider the dyad consisting of South Africa and Lesotho, which are both former British colonies. Lesotho is landlocked within South Africa, so this dyad would be likely to have a high degree of cultural similarity. The value of CULTURE for this dyad is 2.59, the maximum value CULTURE takes in the sample (see Table II). For CIVILLIB and POLRIGHTS, the values are 3.10 and 2.82 respectively. Both of these values are also the maximum values these variables take in the sample. Next, consider India and Australia. Both are former British colonies, but we would not expect them to be as similar as South Africa and Lesotho. For the India/Australia dyad, CULTURE takes a value of zero. CIVILLIB takes a value of 2.07, which is a little above the sample mean of 1.97. POLRIGHTS is 2.35, which is above the sample mean by about three-quarters of a standard deviation. Compared to the South Africa/ Lesotho dyad, CULTURE has been reduced to nothing, whereas CIVILLIB and POLRIGHTS, two variables that are likely to be influenced by membership in the British Empire, still have values above the sample mean. Finally, consider India and Uruguay. Since Uruguay is not a former British colony, we would expect the values of CIVILLIB and POLRIGHTS to be lower in the case of the India/Uruguay dyad than in the previous examples. They are 1.55 and 0.94 respectively. 


\section{EMPIRICAL RESULTS}

A standard binomial test of proportions is used to examine whether each variable is associated, either negatively or positively, with the occurrence of economic sanctions. Specifically, for each variable, the dyads are split into two groups: dyads for which the variable in question takes a value above its median, indicating that the two countries are similar with regard to this variable; and dyads for which the variable in question takes a value below its median, indicating that the two countries are dissimilar with regard to this variable. Then we test whether the proportion of dyads experiencing an economic sanction is statistically significantly different for these two groups of dyads. This process is repeated for each variable, and the results are reported in Table III. BOTHDEM and COLONY are dummy variables whose medians would have to be equal to zero or one, since those are the only values they can take. For these variables, 0.5 , rather than the median, is used as a dividing line to form the two groups of dyads. ${ }^{48}$

Table III reveals statistically significant differences in proportions for CULTURE, CIVILLIB, POLRIGHTS, GOVGDP, GDPPOP, TRADEGDP and BOTHDEM. All of these results are significant at a $1 \%$ error level, except for CULTURE, which is significant at $10 \%$. For these variables, the difference between the likelihood of experiencing an economic sanction among the dyads that ranked above the median, indicating a high degree of dyadic similarity, and the likelihood of experiencing an economic sanction among the dyads where the countries were dissimilar and had a value below the median, was statistically significant. For example, dyads with above-median values of CULTURE, indicating cultural similarity within the dyads, had a 0.0446 probability of experiencing an economic sanction between them, whereas dyads with below-median values of CULTURE, indicating dissimilar cultures, had a 0.0608 probability of experiencing an economic sanction. This difference is statistically significant at a $10 \%$ error level, supporting our hypothesis that countries with similar cultures are less likely to impose economic sanctions against each other than are countries with dissimilar cultures.

TABLE III Proportion of Dyads with Sanctions Grouped by Countries with Similar Characteristics vs. Those with Different Characteristics for Each Variable

\begin{tabular}{|c|c|c|c|c|}
\hline Variable & $\begin{array}{l}\text { Proportion of dyads with a } \\
\text { sanction, for dyads with } \\
\text { similar countries (dyad has } \\
\text { above median value for } \\
\text { specified variable) })^{a}\end{array}$ & $\begin{array}{c}\text { Proportion of dyads with a } \\
\text { sanction, for dyads with } \\
\text { dissimilar countries (dyad has } \\
\text { below median value for specified } \\
\text { variable) })^{a}\end{array}$ & $\begin{array}{c}\text { Significance level for test } \\
\text { of difference between the } \\
\text { two proportions }\end{array}$ & $n$ \\
\hline CULTURE & 0.0446 & 0.0608 & $10 \%$ & 1848 \\
\hline CIVILLIB & 0.0236 & 0.0891 & $1 \%$ & 1383 \\
\hline POLRIGHTS & 0.0318 & 0.0839 & $1 \%$ & 1518 \\
\hline GOVGDP & 0.0816 & 0.0174 & $1 \%$ & 1496 \\
\hline GDPPOP & 0.0910 & 0.0040 & $1 \%$ & 1494 \\
\hline TRADEGDP & 0.0779 & 0.0181 & $1 \%$ & 1438 \\
\hline BOTHDEM & 0.1802 & 0.0419 & $1 \%$ & 1972 \\
\hline GOVSIM & 0.0561 & 0.0496 & Not sign. & 1779 \\
\hline COLONY & 0.0566 & 0.0486 & Not sign. & 1972 \\
\hline
\end{tabular}

${ }^{\text {a }}$ BOTHDEM and COLONY are dummy variables that take a value of zero or one. 0.5 is used as the dividing line between dyads with similar countries and dyads with dissimilar countries for these variables, because the median for these two variables is zero.

\footnotetext{
${ }^{48}$ Note that TARGETDEM is excluded from the test of proportions in Table III. TARGETDEM is a monadic, not dyadic, variable: its value is a measure of regime type only in the target country and therefore cannot be interpreted to reflect the degree of similarity or dissimilarity between the two countries in a dyad.
} 
To further examine the decision to sanction, we utilize probit regressions where the dependent variable is equal to one if a sanction occurred between the dyad countries, zero otherwise (see Table IV). The CULTURE coefficient estimates are not statistically significant at any traditional error level; they are significant at approximately a $16 \%$ error level in each of the two regressions. This is not surprising as CULTURE was significant at a $10 \%$ error level in the comparison of proportions reported in Table III, and here, in the probit regressions, the effects of the other independent variables are being accounted for. The CULTURE variable cannot be used to determine whether a sanction will occur, but it should not be dismissed. It does seem to play a role at the margin.

Of the 98 sanctions episodes represented in the data, 58 featured the United States as the sanctioning country, and one episode featured the United States as the target (the Soviet Union imposed sanctions on the United States in 1948). The average value of CULTURE for the 58 episodes in which the United States imposed economic sanctions is 1.10, below the mean of 1.46 for the sample. ${ }^{49}$ If all dyads containing the United States are included, whether a sanction occurred between the countries in a dyad or not, the mean value of CULTURE decreases to 1.03 , still below the sample mean. It follows that, empirically, the United States displays a lack of cultural linkages, i.e. its level of cultural ties with other countries is below average. Also, the United States imposes economic sanctions disproportionately compared to other countries,

TABLE IV Probit Regression Results for Country Dyads (The Dependent Variable is a Dummy Variable $=1$ if a Sanction Occurred, 0 Otherwise)

\begin{tabular}{lcc}
\hline Variable & Regression 1 & Regression 2 \\
\hline Constant & -7.906 & -7.704 \\
& $(1.135)^{\mathrm{b}}$ & $(1.102)^{\mathrm{b}}$ \\
CULTURE & -0.319 & -0.296 \\
& $(0.223)$ & $(0.215)$ \\
CIVILLIB & -0.701 & -0.725 \\
& $(0.317)^{\mathrm{a}}$ & $(0.374)^{\mathrm{a}}$ \\
POLRIGHTS & 0.053 & 0.080 \\
& $(0.300)$ & $(0.290)$ \\
GOVGDP & -0.664 & -0.628 \\
& $(0.183)^{\mathrm{b}}$ & $(0.177)^{\mathrm{b}}$ \\
GDPPOP & 2.671 & 2.590 \\
& $(0.400)^{\mathrm{b}}$ & $(0.386)^{\mathrm{b}}$ \\
TRADEGDP & 0.194 & 0.175 \\
& $(0.554)$ & $(0.164)$ \\
TARGETDEM & -0.442 & \\
BOTHDEM & $(0.555)$ & -0.089 \\
& & $(0.620)$ \\
GOVSIM & & 0.004 \\
COLONY & 0.020 & $(0.122)$ \\
& $(0.125)$ & 0.617 \\
Pseudo- $R^{2}$ & 0.635 & $(0.428)$ \\
$N$ & $(0.432)$ & 0.88 \\
& 0.89 & 1383 \\
\hline
\end{tabular}

Numbers in parentheses are standard errors.

a significant at a $5 \%$ error level.

b significant at a $1 \%$ error level.

\footnotetext{
${ }^{49}$ This result holds if the one sanction in which the United States was a target is included.
} 
consistent with our expectation that nations with weak cultural linkages are more likely to resort to economic sanctions. Of course, we do not claim that a lack of cultural ties is the only explanation for the United States' proclivity to sanction: there are other reasons, too, why the United States is more likely than other countries to use sanctions, such as its wealth and its great power status (see Lektzian and Souva, 2003: 652).

The results in Table III for CIVILLIB exhibit a pattern like CULTURE: pairs of countries that are similar with regard to these characteristics are less likely to experience an economic sanction between them than are dissimilar pairs of countries. The empirical result is stronger here with the difference in proportions being statistically significant at a $1 \%$ error level. In the probit regressions in Table IV, the CIVILLIB coefficient estimates are statistically significant with the expected negative sign at a 2-3\% error level in both regressions. The United States contributes to these results in the same manner that it did in the case of CULTURE. In dyads where the United States imposed an economic sanction, the mean of CIVILLIB is 1.33, below the overall sample mean of 1.97 and the median of 2.07. These results hold if the single dyad in which the United States was a target is included, and they also hold if all dyads featuring the United States are included, whether a sanction occurred between the countries in a dyad or not. POLRIGHTS is significant in the comparison of proportions in Table III, but it is not significant in the probit regressions. POLRIGHTS and CIVILLIB share a correlation coefficient of 0.74 , and when all of the independent variables are controlled for, it is the index of civil liberties that makes a contribution to the decision to sanction rather than the index of political rights. ${ }^{50}$

GDPPOP exhibits differences in proportions of sanctions that are significant at a $1 \%$ error level, but here the difference runs in the opposite direction. Pairs of nations with similar standards of living are more likely to experience economic sanctions than are pairs of nations with distinctly unequal standards of living. This finding may seem counterintuitive at first, but recall that we have grouped the dyads into two categories for each variable, one in which the countries are more similar than average, and the other in which they are less similar than average. This approach suggests, for example, that the United States is more likely to impose sanctions against South Africa than Ethiopia, but it does not mean that the United States (or any other nation) imposes sanctions only against nations that have roughly the same standard of living as its own. Our result implies simply that sanctioning countries are more likely to impose sanctions against targets whose standards of living are more similar than dissimilar compared with all of the dyads in the sample. (In 2005, the United States ranked eighth in GDP per capita, South Africa ranked 62nd and Ethiopia ranked 177th out of $180 .{ }^{51}$ ) This result holds up in the probit regressions. ${ }^{52}$

When both nations in a dyad are democracies, there is a 0.18 probability of a sanction occurring between them; otherwise there is only a 0.04 probability. In the probit regressions, both dummy variables that test the economic peace hypothesis, BOTHDEM and TARGETDEM, are statistically insignificant. These findings call into question the notion that democracies are relatively unlikely to impose sanctions against other democracies. The statistically significant result for TRADEGDP shown in Table III does not hold up in the probit regressions in Table

\footnotetext{
${ }^{50}$ Examining the correlation matrix for the independent variables reveals one possible multicollinearity problem, as indicated by the 0.74 correlation coefficient of CIVILLIB and POLRIGHTS. If POLRIGHTS is removed from the regression, CIVILLIB becomes significant at a $1 \%$ error level, with the rest of the results coming out about the same. If POLRIGHTS is included and CIVILLIB is omitted, the results for the other independent variables are similar to those shown in Table IV.

${ }^{51} \mathrm{http}: / /$ en.wikipedia.org/wiki/List_of_countries_by_GDP_(nominal)_per_capita.

52 The finding that sanctions are more likely to occur between countries with similar income levels than dissimilar might be due to the fact that sanctions applied by a very poor country against a very rich country would likely be futile, while sanctions applied by a very rich country against a very poor country might be perceived as untoward bullying.
} 
IV. In addition, although the GOVGDP coefficient estimates are significant at a $1 \%$ error level in Table IV, they have the opposite sign (negative) to what would be expected when compared to Table III. For GOVSIM and COLONY, the differences between the two groups of dyads in terms of the proportions of dyads experiencing sanctions are not statistically significant.

The evidence presented provides some support for our proposition that cultural ties between two nations make it less likely that sanctions will take place. Hufbauer et al.'s (1990) ratings of sanctions effectiveness can be used to test our second hypothesis that, when nations with cultural ties do end up experiencing economic sanctions between them, the sanctions are more effective than average. In this test we use ordinal regression, an estimation technique that is appropriate because the dependent variable, HSE's sanctions success ratings (SUCCESS), takes a limited number of discrete values and equal differences between these values may not actually represent equal differences in sanctions success (McCullagh, 1980). Table V contains descriptive statistics for all variables used in the ordinal regression analysis. ${ }^{53}$ Table VI presents results for two ordinal regression equations where SUCCESS is the dependent variable and the variables used above are the independent variables. (Note that ordinal regression models do not have a constant term.)

The HSE dataset contains only dyads where sanctions occurred. There are 69 dyads for which no independent variables are missing. A biased sample could exist in this situation because these 69 dyads are all dyads in which a sanction occurs. As pointed out in the previous section, such a biased sample gives rise to a problem of endogeneity of the decision to use sanctions and the success of the sanctions. In order to address this issue, we need to add nonsanction dyads to the sample. However, if random non-sanction dyads were simply added, there could be a problem with selection bias. This problem potentially arises because the countries represented in the non-sanction dyads might share hidden characteristics that make them different from the countries that are involved in sanctions episodes, and the ordinal regression process might measure these hidden characteristics instead of what we are trying to measure, namely, factors that contribute to sanctions success. ${ }^{54}$

TABLE V Means and Standard Deviations for Regression Sample, Sanctions Dyads and Non-Sanction Dyads (No Observations are Missing any Variables; Includes Random Sample for Non-sanction Dyads)

\begin{tabular}{|c|c|c|c|c|c|c|}
\hline \multirow[b]{2}{*}{ Variable } & \multicolumn{2}{|c|}{$\begin{array}{l}\text { Sample } \\
n=138\end{array}$} & \multicolumn{2}{|c|}{$\begin{array}{c}\text { Sanctions dyads } \\
n=69\end{array}$} & \multicolumn{2}{|c|}{$\begin{array}{c}\text { Non-sanction dyads } \\
n=69\end{array}$} \\
\hline & Mean & $\begin{array}{l}\text { Standard } \\
\text { Deviation }\end{array}$ & Mean & $\begin{array}{l}\text { Standard } \\
\text { Deviation }\end{array}$ & Mean & $\begin{array}{l}\text { Standard } \\
\text { Deviation }\end{array}$ \\
\hline SUCCESS & 3.8116 & 5.02047 & 7.6232 & 4.61488 & 0.0000 & 0.00000 \\
\hline CULTURE & 1.2371 & 0.92802 & 0.1159 & 0.32250 & 1.4020 & 0.78907 \\
\hline CIVILLIB & 1.7013 & 0.91017 & 1.3715 & 0.92517 & 2.0310 & 0.76967 \\
\hline POLRIGHTS & 1.5005 & 0.91252 & 1.3027 & 0.96898 & 1.6983 & 0.81198 \\
\hline GOVGDP & 5.1009 & 0.89932 & 5.4623 & 0.87254 & 4.7396 & 0.77659 \\
\hline GDPPOP & 4.0257 & 1.63998 & 5.4623 & 0.87254 & 2.5892 & 0.68489 \\
\hline TRADEGDP & 0.2391 & 0.42811 & 4.9062 & 0.98060 & 3.9130 & 0.90831 \\
\hline TARGETDEM & 0.1957 & 0.39815 & 0.2319 & 0.42513 & 0.2464 & 0.43406 \\
\hline BOTHDEM & 0.1522 & 0.36050 & 0.2319 & 0.42513 & 0.0725 & 0.26115 \\
\hline GOVSIM & 3.4119 & 1.50515 & 3.6067 & 1.59958 & 3.2171 & 1.38874 \\
\hline COLONY & 0.1014 & 0.30302 & 0.1304 & 0.33925 & 0.0725 & 0.26115 \\
\hline
\end{tabular}

\footnotetext{
${ }^{53}$ Table V differs from Table II in that only observations that are used in the regression analysis (observations for which no independent variables are missing) are included.

${ }^{54}$ For a general discussion of this type of bias, see Judge et al. (1985: 779-785).
} 
TABLE VI Ordinal Regression Results for Country Dyads (Dependent Variable: SUCCESS)

\begin{tabular}{|c|c|c|}
\hline Variable & Regression 1 & Regression 2 \\
\hline CULTURE & $\begin{array}{c}0.885 \\
(0.287)^{b}\end{array}$ & $\begin{array}{c}0.889 \\
(0.286)^{\mathrm{b}}\end{array}$ \\
\hline CIVILLIB & $\begin{array}{c}-0.761 \\
(0.447)^{\mathrm{a}}\end{array}$ & $\begin{array}{c}-0.738 \\
(0.447)^{\mathrm{a}}\end{array}$ \\
\hline POLRIGHTS & $\begin{array}{c}0.230 \\
(0.421)\end{array}$ & $\begin{array}{c}0.177 \\
(0.430)\end{array}$ \\
\hline GOVGDP & $\begin{array}{l}-3.062 \\
(0.601)^{b}\end{array}$ & $\begin{array}{l}-3.060 \\
(0.602)^{\mathrm{b}}\end{array}$ \\
\hline GDPPOP & $\begin{array}{l}3.639 \\
(0.617)^{b}\end{array}$ & $\begin{array}{c}3.621 \\
(0.618)^{\mathrm{b}}\end{array}$ \\
\hline TRADEGDP & $\begin{array}{c}-0.236 \\
(0.228)\end{array}$ & $\begin{array}{c}-0.251 \\
(0.229)\end{array}$ \\
\hline TARGETDEM & $\begin{array}{c}0.645 \\
(0.562)\end{array}$ & \\
\hline BOTHDEM & & $\begin{array}{c}0.786 \\
(0.584)\end{array}$ \\
\hline GOVSIM & $\begin{array}{c}-0.044 \\
(0.084)\end{array}$ & $\begin{array}{c}-0.039 \\
(0.152)\end{array}$ \\
\hline COLONY & $\begin{array}{c}0.681 \\
(0.642)\end{array}$ & $\begin{array}{c}0.685 \\
(0.644)\end{array}$ \\
\hline Pseudo- $R^{2}$ & 0.70 & 0.70 \\
\hline$N$ & 138 & 138 \\
\hline
\end{tabular}

Numbers in parentheses are standard errors.

a significant at a $10 \%$ error level.

b significant at a $1 \%$ error level.

To avoid this possibility of selection bias, we formed a subset of the sample where none of the dyads experienced an economic sanction, yet all of the countries in the subset had been involved in an economic sanction with a different country. Therefore, the countries in the nonsanction portion of the sample have the same hidden characteristics common to the countries in the sanctions portion of the sample since they are the same countries, although matched up differently within the dyads. For example, one of the dyads in the non-sanction subset is the United Kingdom and Uruguay. Each of these countries has been involved in at least one economic sanction, but not with each other. Thus, both the United Kingdom and Uruguay have characteristics that would lead them to be involved in an economic sanction, although no episode of sanctions occurred between them. Sixty-nine observations were chosen at random from this special subset of the sample and were added to the 69 dyads where a sanction occurred to form a balanced sample with 138 observations. Within this sample, the non-sanction dyads act as a control group for the sanctions dyads.

The results are reported in Table VI. There are two regression equations, the only difference between them being that one includes TARGETDEM (the dummy variable for a democratic target) and the other uses BOTHDEM (the dummy variable for democratic sanctioner and target) instead. The CULTURE coefficient estimates are positive and statistically significant at a $1 \%$ error level in both regressions. This result supports our hypothesis that, when nations with cultural ties experience an economic sanction between them, the sanction is more effective than sanctions occurring between countries with fewer cultural connections, ceteris paribus. Consider the CULTURE coefficient estimate in the first regression equation, 0.89. Recall that CULTURE is constructed by dividing by a standard deviation. The reported coefficient estimate can be interpreted to mean that, if the countries in a given dyad are one standard deviation more culturally similar than the countries in 
another dyad, an economic sanction between the more similar pair of countries will have an HSE success rating that is 0.89 points higher than that for the less similar pair, ceteris paribus. The mean of SUCCESS is 3.8 , therefore a change of 0.89 points in the success rating represents approximately $23 \%$ of the value of the mean. The coefficients for the other variables that are divided by standard deviations can be interpreted in the same manner.

GOVGDP and GDPPOP also have statistically significant coefficient estimates, at a $1 \%$ error level, in both regressions in Table VI. The GOVGDP coefficient estimates are negative, indicating that dyads in which the two countries are similar in terms of the sizes of their public sectors are less likely to experience successful economic sanctions than dyads in which the countries have dissimilar-sized public sectors. The GDPPOP coefficient estimates are positive, indicating that, for pairs of countries with roughly similar standards of living, sanctions are likely to be more effective than for pairs with very dissimilar levels of per capita income.

The remaining independent variables in the regression models reported in Table VI have insignificant coefficient estimates (except for CIVILLIB, which is significant at a $10 \%$ error level). This lack of significance can be of some interest. For example, since BOTHDEM has an insignificant coefficient estimate in the regression equation in which it appears, the results here do not support any hypothesis that claims sanctions are either more effective or less effective when both countries are democracies. TARGETDEM also has an insignificant coefficient estimate, meaning that our results do not support any conclusion to the effect that, when the target country is a democracy, sanctions will be either more or less effective. This finding is contrary to Lektzian and Souva (2003) who argue that sanctions are less effective when imposed against democracies than against autocracies and also contrary to Bolks and Al-Sowayel (2000) and Nooruddin (2002) who contend that sanctions imposed against democratic targets are more successful than those imposed against autocracies. The theoretical discussion in Section 2 above suggests that sanctions might be expected to be more effective when sender and target nation are connected by a history of colonial relationships, but the COLONY coefficient estimates in Table VI are not statistically significant.

The results shown in Table VI are robust to removing any one of the variables that has insignificant coefficient estimates. More specifically, if any one of the independent variables with insignificant results is removed from the model, CULTURE, GOVGDP and GDPPOP remain statistically significant with similar coefficient estimates.

An important caveat in the foregoing analysis stems from our use of a geographicallybased measure that may not accurately capture many relevant dimensions of social culture. In an attempt to remedy this shortcoming, we tried including some more direct, and arguably more appropriate, measures, namely, ethnicity, religion and language. However, the coefficient estimates generated by this expanded model either were statistically insignificant or had contradictory signs. The problem arises essentially because social culture is a multidimensional attribute that is not easily observed, quantified or captured by traditional independent variables in a regression model. The empirical literature on cross-country cultural variation reveals little consensus on measurement, with variables ranging from the conventional, such as geographical proximity and language (Goodfriend and McDermott, 1998; Rauch, 1999), to the more creative, such as genealogical, genetic or somatic similarities (Spolaore and Wacziarg, 2009; Guiso et al., 2009), and even, in the case of Felbermayr and Toubal (2010), scores from the Eurovision Song Contest. Clearly, there is substantial insight to be gained, and much progress still to be made, in finding effective methods of measuring various dimensions of culture and incorporating them into studies such as the present one. 


\section{CONCLUSION}

The literature on economic sanctions suggests the importance of institutional attributes of nations in determining both the likelihood that sanctions will be implemented and the likelihood of success of sanctions in attaining their intended political goals. The presence of political and economic institutional similarities between nations is expected to influence conflict propensities (Souva, 2004). This latter insight, deriving originally from the democratic peace hypothesis, has been applied to economic sanctions, where much of the focus in the literature has been on the role of political regime type, i.e. democracy versus autocracy, in determining both the choice of policy instrument and the political outcome. We have extended this approach to embrace cultural similarities between sanctioning and target countries, with culture broadly conceived to include political, economic and social dimensions. We hypothesize that sanctions are more likely to be used when sender and target states have weak cultural linkages than in situations of close cultural ties. We further hypothesize, however, that sanctions will be more effective when sanctioner and target are culturally similar than when they are culturally dissimilar.

Our empirical results demonstrate some support for our claim that states with close cultural ties are less likely to apply economic sanctions against each other than countries without such cultural linkages. At the same time, we also find that economic sanctions occurring between nations with cultural ties are likely to be more effective than sanctions occurring between nations lacking shared cultural attributes. We find no evidence of an economic peace among democracies, i.e. the proposition that democracies typically do not sanction other democracies. However, our findings do help to shed light on two of the most enduring puzzles in the sanctions literature: namely, why sanctions are used so frequently as instruments of foreign policy despite a general perception of ineffectuality, and why the United States is by far the most prolific sanctioner. We have presented empirical evidence that the United States displays a distinct lack of cultural ties with other countries compared to the norm. This absence of cultural linkages means that the United States is denied access to alternative channels of influence that could be opened up to resolve international disputes, hence the excessive reliance on sanctions as well as their observed prevalence as a tool of foreign policy. At the same time, however, the lack of cultural ties between the United States and its adversaries also means that most sanctions that are implemented are likely to be relatively ineffective.

\section{ACKNOWLEDGMENTS}

We thank Wenhui Fan and other participants in a session of the Canadian Economics Association annual conference (Vancouver, BC, June 7, 2008) for helpful comments. We are also grateful for valuable suggestions from the editor and referees. All remaining errors, however, are the responsibility of the authors alone. We thank Mathew Dunn and Alexis Neal for research assistance.

\section{References}

Acemoglu, D., Johnson, S.H. and Robinson, J.A. (2001) The colonial origins of comparative development: An empirical investigation. American Economic Review 91(December) 1369-1401.

Acemoglu, D., Johnson, S.H. and Robinson, J.A. (2002a) An African success story: Botswana. CEPR Discussion Paper No. 3219. London: Centre for Economic Policy Research.

Acemoglu, D., Johnson, S.H. and Robinson, J.A. (2002b) Reversal of fortune: geography and institutions in the making of the modern world income distribution. Quarterly Journal of Economics 117(November) 1231-1294.

Acemoglu, D., Johnson, S.H. and Robinson, J.A. (2004) Institutions as the fundamental cause of long-run growth. NBER Working Paper No. 10481. Cambridge, MA: National Bureau of Economic Research. 
Alerassool, M. (1993) Freezing Assets: The USA and the Most Effective Economic Sanction. New York: St. Martin's Press.

Allen, S.H. (2005) The determinants of economic sanctions success and failure. International Interactions 31(January) $117-138$

Allen, S.H. (2008) The domestic political costs of economic sanctions. Journal of Conflict Resolution 52(December) 916-944.

Baldwin, D.A. (1985) Economic Statecraft. Princeton, NJ: Princeton University Press.

Beck, T., Clarke, G., Groff, A., Keefer, P. and Walsh, P. (2001) New tools and new tests in comparative political economy: the database of political institutions. World Bank Economic Review 5(September) 165-176.

Beck, T., Demirgüç-Kunt, A. and Levine, R. (2003) Law, endowments, and finance. Journal of Financial Economics 70(November) 137-181.

Bernhard, M., Reenock, C. and Nordstrom, T. (2004) The legacy of Western overseas colonialism on democratic survival. International Studies Quarterly 48(March) 225-250.

Bertocchi, G. and Canovab, F. (2002) Did colonization matter for growth? An empirical exploration into the historical causes of Africa's underdevelopment. European Economic Review 46(December) 1851-1871.

Blake, C.H. and Klemm, N. (2006) Reconsidering the effectiveness of international economic sanctions: an examination of selection bias. International Politics 43(February) 133-149.

Bolks, S.M. and Al-Sowayel, D. (2000) How long do economic sanctions last? Examining the sanctioning process through duration. Political Research Quarterly 53(June) 241-265.

Bonetti, S. (1997) The analysis and interpretation of economic sanctions. Journal of Economic Studies 24(5) 324-348.

Bonetti, S. (1998) Distinguishing characteristics of degrees of success and failure in economic sanctions episodes. Applied Economics 30(June) 805-813.

Bueno de Mesquita, B., Morrow, J.D., Siverson, R.M. and Smith, A. (1999) An institutional explanation of the democratic peace. American Political Science Review 93(December) 791-807.

Bueno de Mesquita, B. and Siverson, R.M. (1995) War and the survival of political leaders: a comparative study of regime types and political accountability. American Political Science Review 89(December) 841-855.

Bueno de Mesquita, B., Smith, A., Siverson, R.M. and Morrow, J.D. (2003) The Logic of Political Survival. Cambridge, MA: MIT Press.

Clague, C., Keefer, P., Knack, S. and Olson, M., Jr. (1999) Contract-intensive money: Contract enforcement, property rights, and economic performance. Journal of Economic Growth 4(June) 185-211.

Cortright, D. and Lopez, G.A. (2000) The Sanctions Decade: Assessing UN Strategies in the 1990s. Boulder, CO: Lynne Rienner Publishers.

Cortright, D. and Lopez, G.A. (2002a) Sanctions and the Search for Security: Challenges to UN Action. Boulder, CO: Lynne Rienner Publishers.

Cortright, D. and Lopez, G.A. (Eds) (2002b) Smart Sanctions: Targeting Economic Statecraft. Lanham, MD: Rowman and Littlefield.

Cortright, D., Lopez, G.A. and Rogers, E.S. (2002) Targeted financial sanctions: smart sanctions that do work. In Smart Sanctions: Targeting Economic Statecraft, edited by D. Cortright and G.A. Lopez. Lanham, MD: Rowman and Littlefield, 23-40.

Cortright, D., Millar, A. and Lopez, G.A. (2002) Smart sanctions in Iraq: policy options. In Smart Sanctions: Targeting Economic Statecraft, edited by D. Cortright and G.A. Lopez. Lanham, MD: Rowman and Littlefield, 201-224.

Cox, D.G. and Drury, A.C. (2006) Democratic sanctions: connecting the democratic peace and economic sanctions. Journal of Peace Research 43(November) 709-722.

Damrosch, L.F. (1993) The civilian impact of economic sanctions. In Enforcing Restraint: Collective Intervention in Internal Conflicts, edited by L.F. Damrosch. New York: Council on Foreign Relations Press, 274-315.

Danilovic, V. and Clare, J. (2007) The Kantian liberal peace (revisited). American Journal of Political Science 51(April) 397-414.

Dashti-Gibson, J., Davis, P. and Radcliff, B. (1997) On the determinants of the success of economic sanctions: an empirical analysis. American Journal of Political Science 41(April) 608-618.

Davidson, J. and Shambaugh, G. (2000) Who's afraid of economic incentives? The efficacy-externality tradeoff. In Sanctions as Economic Statecraft: Theory and Practice, edited by S. Chan and A.C. Drury. London: Macmillan, $37-64$.

Dehejia, R.H. and Wood, B. (1992) Economic sanctions and econometric policy evaluation: a cautionary note. Journal of World Trade 26(February) 73-84.

DeRouen, K.R., Jr. and Goldfinch, S. (2005) Putting the numbers to work: implications for violence prevention. Journal of Peace Research 42(January) 27-45.

Dixon, W.J. (1994) Democracy and the peaceful settlement of international conflict. American Political Science Review 88(March) 14-32.

Dixon, W.J. and Senese, P.D. (2002) Democracy, disputes, and negotiated settlements. Journal of Conflict Resolution 46(August) 547-571.

Doucouliagos, H. and Ulubaşoğlu, M.A. (2008) Democracy and economic growth: a meta-analysis. American Journal of Political Science 52(January) 61-83.

Doxey, M.P. (1980) Economic Sanctions and International Enforcement, 2nd edn. New York: Oxford University Press.

Doxey, M.P. (1996) International Sanctions in Contemporary Perspective, 2nd edn. London: Macmillan. 
Drezner, D.W. (1998) Conflict expectations and the paradox of economic coercion. International Studies Quarterly 42(December) 709-731.

Drezner, D.W. (1999) The Sanctions Paradox: Economic Statecraft and International Relations. Cambridge: Cambridge University Press.

Drezner, D.W. (2000) The trouble with carrots: transaction costs, conflict expectations, and economic inducements. Security Studies 9(1/2) 188-218.

Drezner, D.W. (2001) Outside the box: explaining sanctions in pursuit of foreign economic goals. International Interactions 26(4) 379-410.

Drezner, D.W. (2003) The hidden hand of economic coercion. International Organization 57(Summer) 643-659.

Drury, A.C. (1998) Revisiting Economic Sanctions Reconsidered. Journal of Peace Research 35(July) 497-509.

Easterly, W. (2006) The White Man's Burden: Why the West's Efforts to Aid the Rest Have Done So Much Ill and So Little Good. New York: Penguin Books.

Eaton, J. and Engers, M. (1992) Sanctions. Journal of Political Economy 100(October) 899-928.

Eaton, J. and Engers, M. (1999) Sanctions: some simple analytics. American Economic Review 89(May) 409-414.

Escribà-Folch, A. (2010) Economic sanctions and the duration of civil conflicts. Journal of Peace Research 47(March) 129-141.

Farnham, B. (2003) The theory of democratic peace and threat perception. International Studies Quarterly 47(September) 395-415.

Fearon, J.D. (1994) Domestic political audiences and the escalation of international disputes. American Political Science Review 88(September) 577-592.

Felbermayr, G.J. and Toubal, F. (2010) Cultural proximity and trade. European Economic Review 54(February) $283-297$.

Feng, Y. (2003) Democracy, Governance, and Economic Performance: Theory and Evidence. Cambridge, MA: MIT Press.

Feyrer, J. and Sacerdote, B. (2009) Colonialism and modern income: islands as natural experiments. Review of Economics and Statistics 91(May) 245-262.

Freedom House (2005) Freedom in the World 2005: The Annual Survey of Political Rights and Civil Liberties, Lanham, MD: Rowman and Littlefield. http://www.freedomhouse.org/template.cfm?page=211\&year=2005.

Galtung, J. (1967) On the effects of international economic sanctions, with examples from the case of Rhodesia. World Politics 19(April) 378-416.

Gartzke, E. (2000) Preferences and the democratic peace. International Studies Quarterly 44(June) 191-212.

Goenner, C.F. (2007) Economic war and democratic peace. Conflict Management and Peace Science 24(3) 171-182.

Goodfriend, M. and McDermott, J. (1998) Industrial development and the convergence question. American Economic Review 88(December) 1277-1289.

Grier, R.M. (1999) Colonial legacies and economic growth. Public Choice 98(March) 317-335.

Guiso, L., Sapienza, P. and Zingales, L. (2009) Cultural biases in economic exchange? Quarterly Journal of Economics 124(August) 1095-1131.

Haass, R.N. (Ed.) (1998) Economic Sanctions and American Diplomacy. New York: Council on Foreign Relations Press.

Hafner-Burton, E.M. and Montgomery, A.H. (2008) The hegemon's purse: no economic peace between democracies. Journal of Peace Research 45(January) 111-120.

Hanlon, J. and Omond, R. (1987) The Sanctions Handbook. Harmondsworth: Penguin Books.

Hart, R.A. (2000) Democracy and the successful use of economic sanctions. Political Research Quarterly 53(June) 267-284.

Helpman, E. (2004) The Mystery of Economic Growth. Cambridge, MA: Belknap Press.

Henderson, E.A. (1998) The democratic peace through the lens of culture, 1820-1989. International Studies Quarterly 42(September) 461-484.

Henderson, E.A. (1999) Neoidealism and the democratic peace. Journal of Peace Research 36(March) $203-231$.

Henderson, E.A. (2002) Democracy and War: The End of an Illusion? Boulder, CO: Lynne Rienner Publishers.

Hess, G.D. and Orphanides, A. (2001) War and democracy. Journal of Political Economy 109(August) 776-810.

Heston, A., Summers, R. and Aten, B. (2002) Penn World Table, Version 6.1, http://pwt.econ.upenn.edu/. Philadelphia, PA: Center for International Comparisons at the University of Pennsylvania (CICUP).

Hillman, A.L. and Swank, O. (2000) Why political culture should be in the lexicon of economics. European Journal of Political Economy 16(March) 1-4.

Hufbauer, G.C. (1998) Sanctions-happy U.S.A. International Economics Policy Brief No. 98-4. Washington, DC: Peter G. Peterson Institute for International Economics.

Hufbauer, G.C. and Schott, J.J. (1985) Economic Sanctions Reconsidered: History and Current Policy. Washington, DC: Peter G. Peterson Institute for International Economics.

Hufbauer, G.C., Schott, J.J. and Elliott, K.A. (1990) Economic Sanctions Reconsidered: History and Current Policy, 2nd edn. Washington, DC: Peter G. Peterson Institute for International Economics.

Hufbauer, G.C., Schott, J.J., Elliott, K.A. and Oegg, B. (2007) Economic Sanctions Reconsidered, Third Edition. Washington, DC: Peter G. Peterson Institute for International Economics.

James, P., Solberg, E. and Wolfson, M. (1999) An identified systemic model of the democracy-peace nexus. Defence and Peace Economics 10(1) 1-37.

James, P., Solberg, E. and Wolfson, M. (2000) Democracy and peace: reply to Oneal and Russett. Defence and Peace Economics 11(2) 215-229. 
Jing, C., Kaempfer, W.H. and Lowenberg, A.D. (2003) Instrument choice and the effectiveness of international sanctions: a simultaneous equations approach. Journal of Peace Research 40(September) 519-535.

Judge, G.G., Griffiths, W.E., Hill, R.C., Lütkepohl, H. and Lee, T-C. (1985) The Theory and Practice of Econometrics, 2nd edn. New York: Wiley.

Kaempfer, W.H. and Lowenberg, A.D. (1988) The theory of international economic sanctions: a public choice approach. American Economic Review 78(September) 786-793.

Kaempfer, W.H. and Lowenberg, A.D. (1999) Unilateral versus multilateral international sanctions: a public choice perspective. International Studies Quarterly 43(March) 37-58.

Kaempfer, W.H. and Lowenberg, A.D. (2007) The political economy of economic sanctions. In Handbook of Defense Economics, Vol. 2: Defense in a Globalized World, edited by T. Sandler and K. Hartley. Amsterdam: Elsevier North-Holland, 867-911.

Kaempfer, W.H., Lowenberg, A.D. and Mertens, W. (2004) International economic sanctions against a dictator. Economics and Politics 16(March) 29-51.

Knack, S. and Keefer, P. (1995) Institutions and economic performance: cross-country tests using alternative institutional measures. Economics and Politics 7(November) 207-227.

Krustev, V.L. (2010) Strategic demands, credible threats, and economic coercion outcomes. International Studies Quarterly 54(March) 147-174.

La Porta, R., Lopez-de-Silanes, F., Shleifer, A. and Vishny, R. (1999) The quality of government. Journal of Law, Economics, and Organization 15(April) 222-279.

La Porta, R., Lopez-de-Silanes, F., Pop-Eleches, C. and Shleifer, A. (2002) The guarantees of freedom. NBER Working Paper No. 8759. Cambridge, MA: National Bureau of Economic Research.

La Porta, R., Lopez-de-Silanes, F. and Shleifer, A. (2008) The economic consequences of legal origins. Journal of Economic Literature 46(June) 285-332.

Lacy, D. and Niou, E.M.S. (2004) A theory of economic sanctions and issue linkage: the roles of preferences, information, and threats. Journal of Politics 66(February) 25-42.

Lam, S.L. (1990) Economic sanctions and the success of foreign policy goals: a critical evaluation. Japan and the World Economy 2(3) 239-248.

Leitzel, J. (1987) Review of Hufbauer et al. (1985). Kyklos 40(2) 286-288.

Lektzian, D.J. and Souva, M. (2003) The economic peace between democracies: economic sanctions and domestic institutions. Journal of Peace Research 40(November) 641-60.

Lektzian, D.J. and Souva, M. (2007) An institutional theory of sanctions onset and success. Journal of Conflict Resolution 51(December) 848-871.

Lektzian, D.J. and Souva, M. (2009) A comparative theory test of democratic peace arguments, 1946-2000. Journal of Peace Research 46(January) 17-37.

Lektzian, D.J. and Sprecher, C.M. (2007) Sanctions, signals, and militarized conflict. American Journal of Political Science 51(April) 415-431.

Levine, R. (2005) Law, endowments and property rights. Journal of Economic Perspectives 19(Summer) 6188.

Leyton-Brown, D. (1987) Lessons and policy considerations about economic sanctions. In The Utility of International Economic Sanctions, edited by D. Leyton-Brown. New York: St. Martin's Press, 303-310.

Lopez, G.A. (2001) Toward smart sanctions on Iraq. Policy Brief No. 5. Notre Dame, IN: Joan B. Kroc Institute for International Peace Studies, University of Notre Dame.

Lundborg, P. (1987) The Economics of Export Embargoes: The Case of the U.S.-Soviet Grain Suspension. London: Croom Helm.

Mack, A. and Khan, A. (2000) The efficacy of UN sanctions. Security Dialogue 31(3) 279-292.

Marinov, N. (2005) Do economic sanctions destabilize country leaders? American Journal of Political Science 49(July) 564-576.

Mayall, J. (1984) The sanctions problem in international economic relations: Reflections in the light of recent experience. International Affairs 60(4) 631-642.

McCullagh, P. (1980) Regression models for ordinal data. Journal of the Royal Statistical Society 42(2) 109-142.

Mijiyawa, A.G. (2008) Sustained economic growth: do institutions matter, and which one prevails? Cato Journal 28(Fall) 385-420.

Morgan, T.C. and Miers, A.C. (1999) When threats succeed: a formal model of the threat and use of economic sanctions. Paper presented at the Annual Meeting of the American Political Science Association, Atlanta, GA, September 2-5.

Morgan, T.C. and Palmer, G. (2003) To protect and to serve: Alliances and foreign policy portfolios. Journal of Conflict Resolution 47(April) 180-203.

Morgan, T.C. and Schwebach, V.L. (1995) Economic sanctions as an instrument of foreign policy: the role of domestic politics. International Interactions 21(3) 247-263.

Mousseau, M. (1998) Democracy and compromise in militarized interstate conflicts, 1816-1992. Journal of Conflict Resolution 42(April) 210-230.

Mousseau, M. (2003) The nexus of market society, liberal preferences, and democratic peace: Interdisciplinary theory and evidence. International Studies Quarterly 47(December) 483-510.

Mousseau, M. (2009) The social market roots of democratic peace. International Security 33(Spring) 52-86.

Mousseau, M. and Shi, Y. (1999) A test for reverse causality in the democratic peace relationship. Journal of Peace Research 36(November) 639-663. 
Mulligan, C.B. and Tsui, K.K. (2006) Political competitiveness. NBER Working Paper No. 12653. Cambridge, MA: National Bureau of Economic Research.

Mulligan, C.B. and Tsui, K.K. (2008) Political entry, public policies, and the economy. NBER Working Paper No. 13830. Cambridge, MA: National Bureau of Economic Research.

Nooruddin, I. (2002) Modeling selection bias in studies of sanctions efficacy. International Interactions 28(January) $59-75$.

Nossal, K.R. (1999) Liberal democratic regimes, international sanctions, and global governance. In Globalization and Global Governance, edited by R. Väyrynen. Lanham, MD: Rowman and Littlefield, 127-150.

Olson, M., Jr. (1996) Big bills left on the sidewalk: why some nations are rich, and others poor. Journal of Economic Perspectives 10(Spring) 3-24.

Oneal, J.R. and Russett, B.M. (1997) The classical liberals were right: Democracy, interdependence, and conflict, 1950-1985. International Studies Quarterly 41(June) 267-294.

Paldam, M. (2002) The cross-country pattern of corruption: economics, culture and the seesaw dynamics. European Journal of Political Economy 18(June) 215-240.

Palmer, G., Wohlander, S.B. and Morgan, T.C. (2002) Give or take: Foreign aid and foreign policy substitutability. Journal of Peace Research 39(January) 5-26.

Pape, R.A. (1997) Why economic sanctions do not work. International Security 22(Fall) 90-136.

Partell, P.J. and Palmer, G. (1999) Audience costs and interstate crises: an empirical assessment of Fearon's model of dispute outcomes. International Studies Quarterly 43(June) 389-405.

Peksen, D. (2009) Better or worse? The effect of economic sanctions on human rights. Journal of Peace Research 46(January) 59-77.

Rauch, J.E. (1999) Networks versus markets in international trade. Journal of International Economics 48(June) $7-35$.

Renwick, R. (1981) Economic Sanctions. Cambridge, MA: Center for International Affairs, Harvard University.

Reuveny, R. and Li, Q. (2003) The joint democracy-dyadic conflict nexus: a simultaneous equations model. International Studies Quarterly 47(September) 325-346.

Rodrik, D. (2000a) Institutions for high-quality growth: what they are and how to acquire them. NBER Working Paper No. 7540. Cambridge, MA: National Bureau of Economic Research.

Rodrik, D. (2000b) Participatory politics, social cooperation, and economic stability. American Economic Review 90(May) 140-144.

Rosato, S. (2003) The flawed logic of democratic peace theory. American Political Science Review 97(November) $585-602$.

Rosato, S. (2005) Explaining the democratic peace. American Political Science Review 99(August) 467-472.

Russett, B.M. (1993) Grasping the Democratic Peace. Princeton, NJ: Princeton University Press.

Russett, B.M. and Oneal, J.R. (2001) Triangulating Peace: Democracy, Interdependence, and International Organizations. New York: W.W. Norton.

Russett, B.M. and Starr, H. (2000) From democratic peace to Kantian peace: democracy and conflict in the international system. In Handbook of War Studies, 2nd edn, edited by M. Midlarsky. Ann Arbor, MI: University of Michigan Press, 93-128.

Selden, Z. (1999) Economic Sanctions as Instruments of American Foreign Policy. Westport, CT: Praeger Publishers.

Siverson, R.M. and Emmons, J. (1991) Birds of a feather: Democratic political systems and alliance choices in the twentieth century. Journal of Conflict Resolution, 35(June) 285-306.

Smith, A. (1995) The success and use of economic sanctions. International Interactions 21(3) 229-245.

Souva, M. (2004) Institutional similarity and interstate conflict. International Interactions 30(July) 263-280.

Spolaore, E. and Wacziarg, R.T. (2009) War and relatedness. NBER Working Paper No. 15095. Cambridge, MA: National Bureau of Economic Research.

Tabellini, G. (2008) Institutions and culture. Journal of the European Economic Association 6(April-May) 255-294.

Tabellini, G. (2010) Culture and institutions: economic development in the regions of Europe. Journal of the European Economic Association 8(June) 677-716.

Tostensen, A. and Bull, B. (2002) Are smart sanctions feasible? World Politics 54(April) 373-403.

Tsebelis, G. (1990) Are sanctions effective? A game-theoretic analysis. Journal of Conflict Resolution 34(March) 3-28. van Bergeijk, P.A.G. (1989) Success and failure of economic sanctions. Kyklos 42(3) 385-404.

van Bergeijk, P.A.G. (1994) Economic Diplomacy, Trade and Commercial Policy: Positive and Negative Sanctions in a New World Order. Aldershot: Edward Elgar.

United Nations Statistics Division (annual - various dates) National Accounts Main Aggregates Database, http:// unstats.un.org/unsd/snaama/Introduction.asp. New York: United Nations.

United States Central Intelligence Agency (various dates) The World Factbook, https://www.cia.gov/library/publications/the-world-factbook/index.html. Washington, DC: United States Central Intelligence Agency.

United States Department of State (various dates) Background Notes, http://www.state.gov/r/pa/ei/bgn/. Washington, DC: United States Department of State.

Ward, M.D., Siverson, R.M. and Cao, X. (2007) Disputes, democracies, and dependencies: A reexamination of the Kantian peace. American Journal of Political Science 51(July) 583-601.

Weede, E. (2004) The diffusion of prosperity and peace by globalization. The Independent Review 9(Fall) 165-186.

Weiss, T.G. (1999) Sanctions as a foreign policy tool: weighing humanitarian impulses. Journal of Peace Research 36(September) 499-509.

Willett, T.D. and Jalalighajar, M. (1983/84) U.S. trade policy and national security. Cato Journal 3(Winter) 717-727. 
Wintrobe, R. (1990) The tinpot and the totalitarian: an economic theory of dictatorship. American Political Science Review 84(September) 849-872.

Wintrobe, R. (1998) The Political Economy of Dictatorship. Cambridge: Cambridge University Press.

Wood, R.M. (2008) A hand upon the throat of the nation: economic sanctions and state repression, 1976-2001. International Studies Quarterly 52(September) 489-513.

World Bank (various dates) Database of Political Institutions, http://www.worldbank.org/research/growth/ political_datal.htm. Washington, DC: World Bank.

\section{APPENDIX}

GOVSIM is an index that measures the similarity of the governments of the two nations in a dyad. The index is primarily concerned with the form of government. The components of the index are from http://www.worldbank.org/research/growth/political_datal.htm. The abbreviations used on this webpage are explained in a PDF file found on the same page, entitled Database of Political Institutions Version 3.0. Additional background information about the components can be found in Beck et al. (2001). The components used here to construct GOVSIM are found in the PDF file mentioned above, and are as follows:

SYSTEM $=0$ if presidential, 1 if assembly-elected president, 2 if parliamentary.

EXECRLC = executive branch, $\mathrm{R}$ for right, $\mathrm{L}$ for left, $\mathrm{C}$ for Center, 0 for not applicable.

1GOVRLC = largest government party, $\mathrm{R}$ for right, $\mathrm{L}$ for left, $\mathrm{C}$ for Center, 0 for not applicable.

HERFTOT $=$ Herfindahl index by party for the whole parliament or congress.

LIEC $=$ index of electoral competitiveness for legislature.

EIEC $=$ index of electoral competitiveness for executive branch.

IPCOH = dummy variable measuring degree of political cohesion.

These components are used to construct an aggregate index measuring the similarity of the two governments in each dyad. Below, the method by which each component is incorporated into GOVSIM is described. In general, the values of each component are compared across the two countries in the dyad, and if they are the same (or similar for components that are not dummy variables) a value of one is added to the index, otherwise, zero. (For the components that are not dummy variables, the value added to the index can vary from zero to one.)

SYSTEM: add 1 to GOVSIM if values match across countries; otherwise 0.

EXECRLC: add 1 to GOVSIM if values match across countries; otherwise 0.

1GOVRLC: add 1 to GOVSIM if values match across countries; otherwise 0.

HERFTOT: add abs(HERFTOT value for Country 1-HERFTOT value for Country 2) to GOVSIM. 
LIEC: add abs(LIEC value for Country 1 - LIEC value for Country 2)/7 to GOVSIM.

EIEC: add abs(EIEC value for Country 1-EIEC value for Country 2)/7 to GOVSIM.

IPCOH: add 1 to GOVSIM if values match across countries; otherwise 0.

If a component is not available for one of the nations in the index, a value of 0.5 is added to GOVSIM. If more than a total of two of the seven components are missing for either of the two countries in the dyad, the GOVSIM variable is considered missing for that observation. The theoretical range of GOVSIM is 0-7; the actual range is 0.65-7. 